\title{
Tüketicilerin Kompulsif Satın Alma Davranışını Etkileyen Faktörler: Bir Uygulama (The Factors Effecting Consumers' Compulsive Purchasing Behavior: An Application)
}

\author{
Mehmet Ozan KARAHAN (iD) a, Cevat SÖYLEMEZ (iD) b \\ aUşak Üniversitesi, Eşme Meslek Yüksekokulu, Uşak, Türkiye. mozan.karahan@usak.edu.tr \\ `Kütahya Dumlupınar Üniversitesi, İktisadi ve İdari Bilimler Fakültesi, Kütahya, Türkiye. cevatsoylemez@hotmail.com
}

\begin{tabular}{|c|c|}
\hline MAKALE BİLGİSİ & ÖZET \\
\hline $\begin{array}{l}\text { Anahtar Kelimeler: } \\
\text { Kompulsif Satın Alma } \\
\text { Materyalizm } \\
\text { Satın Alma Sonrası Pişmanlık }\end{array}$ & $\begin{array}{l}\text { Amaç - Bu çalışmanın temel amacı, tüketicilerin kompulsif satın alma davranışları üzerinde } \\
\text { etkili olan değişkenlerin belirlenmesidir. Bu kapsamda materyalizm, özsaygı ve akran } \\
\text { değişkenlerinin tüketicilerin kompulsif satın alma davranışı üzerindeki etkisi araştırılmış̧ır. } \\
\text { Ayrıca tüketicilerin sergilemiş oldukları bu davranışı satın alma sonrası pişmanlık üzerindeki } \\
\text { etkiside ortaya konulmaya çalışılmıştır. }\end{array}$ \\
\hline $\begin{array}{l}\text { Gönderilme Tarihi } 15 \text { Temmuz } \\
2019 \\
\text { Revizyon Tarihi } 25 \text { Ağustos } 2019 \\
\text { Kabul Tarihi } 5 \text { Eylül } 2019\end{array}$ & $\begin{array}{l}\text { Yöntem - Araştırmada ilişkisel araştırma modelinden yararlanılmıştır. Veriler online ve } \\
\text { yüzyüze anketle kolayda örnekleme yöntemi kullanılarak toplanmıştır. Araştırmanın evrenini } \\
\text { Türkiye'deki } 18 \text { yaşından büyük tüketiciler oluşturmaktadır. Toplam } 341 \text { geçerli veri ile } \\
\text { analizler gerçekleştirilmiştir. Verilerin analizi ve öne sürülen araştırma hipotezlerinin testi için } \\
\text { yapısal eşitlik modellemesi kullanılmıştır. }\end{array}$ \\
\hline $\begin{array}{l}\text { Makale Kategorisi: } \\
\text { Araştırma Makalesi }\end{array}$ & $\begin{array}{l}\text { Bulgular - Araştırma sonucunda tüketicilerin kompulsif satın alma davranışı üzerinde } \\
\text { materyalizm ve akran'ın anlamlı, özsaygının ise anlamsız etkisinin olduğu bulunmuştur. Yine } \\
\text { kompulsif satın alma davranışının da tüketicilerin satın alma sonrası ortaya çıkan pişmanlık } \\
\text { duygusu üzerinde etkisinin olduğu ulaşılan bulgular arasındadır. }\end{array}$ \\
\hline & $\begin{array}{l}\text { Tartışma - Tüketicilerin satın alma davranışları her geçen gün değişmektedir. Bu kapsamda } \\
\text { tüketicinin etrafında yer uyaranlar değişimin önemli unsurlarını oluşturmaktadır. Tüketim } \\
\text { alışkanlıklarındaki bu değişim hem bireyden hem de yakın çevredeki bireylerden } \\
\text { kaynaklanmaktadır. Bu nedenle tüketicilerin davranışlarını etkileyen bu unsurların neler } \\
\text { olduğu ve/veya neler olabileceği pazarlama uygulayıcılarının üzerinde durması gereken } \\
\text { konular biridir. }\end{array}$ \\
\hline
\end{tabular}

\begin{tabular}{ll}
\hline ARTICLE INFO & ABSTRACT \\
\hline Keywords: & $\begin{array}{l}\text { Purpose - The main purpose of this study is to determine the variables that affect consumers' } \\
\text { Compulsive buying behaviors. In this context, the effects of materialism, self-esteem and peer } \\
\text { variables on the compulsive buying behavior of consumers were investigated. In addition, the } \\
\text { Materialism } \\
\text { Post purchase regret }\end{array}$ \\
$\begin{array}{l}\text { effect of compulsive buying behavior has been tried to be revealed on post purchase regret. } \\
\text { Design/methodology/approach - Relational research model was used in the study. The data } \\
\text { were collected by online and face-to-face questionnaire using easy sampling method. The } \\
\text { population of the this research is the largest consumer from } 18 \text { years in Turkey. A total of } 341\end{array}$ \\
Received 15 July 2019 & $\begin{array}{l}\text { valid data were analyzed. Structural equation modeling was used to analyze the data and test } \\
\text { the hypotheses proposed. }\end{array}$ \\
Accepted 5 September 2019 & $\begin{array}{l}\text { Findings - As a result of the research, it was found that materialism and peer had a significant } \\
\text { and self-esteem had a meaningless effect on the compulsive buying behavior of consumers. } \\
\text { Hrticle Classification: }\end{array}$ \\
However, compulsive buying behavior has an effect on post-purchase regret. \\
Discussion - Consumer buying behavior is changing with each passing day. In this context, \\
stimuli around the consumer are important elements of the change. This change in consumption \\
habits stems from both individuals and individuals in the immediate environment. Therefore, \\
what is and / or what these factors affect the behavior of consumers is one of the issues that \\
marketing practitioners should focus on.
\end{tabular}




\section{Giriş}

Kompulsif satın alma kavramı psikolojik, sosyolojik ve finansal etkileri sebebiyle araştırmacıların üzerine yoğunlaştığı konuların başında gelmektedir. Öyle ki, bazı araştırmacılar küresel ekonomik krizin derinleşmesinde kontrolsüz harcamaların, rasyonel şekilde kullanılmayan kredilerin ve aşırı tüketimin etkisi olduğunu ifade etmişlerdir (Gardarsdottir ve Dittmar, 2012; Schneider ve Kirchgassner, 2009). İnternet teknolojisinin gelişmesi, özellikle genç yaştaki tüketiciler için rol model olarak görülen ünlülerin ürün ve marka tanıtım ve iletişim çalışmalarında aktif olarak görülmeleri kompulsif satın alma davranışını artıran etkenler olarak sıralanmaktadır (Kaynak ve Harcar, 2001).

Tüketicilerin çoğu zaman rasyonel satın alma davranışı yerine hedonik değerlere bağlı kalarak alışveriş yapmaları; tüketici davranışları alanında çalışan araştırmacıların kompulsif satın alma davranışına ilgilerini artırmıştır. Konu üzerine yoğunlaşan araştırmacılar, kompulsif satın alma davranışının sebeplerini ve sonuçlarını incelerken sosyo-demografik ve psikolojik faktörler üzerinde durmuşlardır (Raab vd., 2011). Yapılan araştırmalarda, maddi durumlarını yönetme becerisinden uzak, özsaygısı düşük, stresle başa çımakta zorlanan ve kendilerini ürün ya da marka ile daha kolay ve sıkça özdeşleştiren bireylerin kompulsif satın alma davranışını sergiledikleri ya da sergileme eğiliminde oldukları belirtilmiştir (Dittmar, 2005; Raab vd., 2011; Ridgway vd., 2008). Kompulsif satın alma sonrası bireylerin hissettikleri de araştırmacılar açısından önemlidir. Kısa süreli rahatlama ve mutlu olmak için alışverişin yeniden yapılması ya da alışveriş sonrası yalnızlık, öfke, suçluluk ve pişmanlık durumları araştırmacılar tarafından belirtilen ifadeler arasında yer almaktadır (Faber ve Vohs, 2004), Mcelroy vd., 1994)

Strizhakova vd., (2008), toplumların düşük sosyo-ekonomik seviyelerden yüksek seviyelere doğru ilerledikçe, bireyler arasında markaların sembolik özelliklerinin daha fazla önem kazandığını ve bunun kompulsif satın alma davranışa etkisinin olduğunu belirtmiştir. Ülkemiz açısından bakıldığında, kompulsif satın alma davranışının özellikle gençler arasındaki durumunu incelemek, davranışa hangi faktörlerin neden olduğu ve sonuçlarının neler olabileceği noktasında yaptığımız araştırmanın literatüre katkı sağlayabileceği umulmaktadır. Araştırmanın amacı doğrultusunda, ilk olarak kompulsif satın alma kavramı ve araştırma modelinde yer alan ve kompulsif satın almaya etkisi olabileceği düşünülen diğer faktörler (materyalizm, özsaygı, akran etkisi ve satın alma sonrası pişmanlık) açılanmaya çalışılmış; literatürde yer alan çalışmalara bakılararak da çalışmanın hipotezleri oluşturulmuştur. Daha sonra ise, anket çalışması sonucu elde edilen verilerin analiz sonuçlarına değinilmiştir. Son olarak sonuç kısmında ise, daha önce yapılan araştırmalarla çalışmamızda ortaya çıkan bulgular karşılaştırılarak değerlendirilmiştir.

\section{Literatür}

\subsection{Kompulsif Satın Alma Davranışı}

Günümüzde kompulsif satın alma davranışı ya da eğilimi, geniş kapsamlı etkileri sebebiyle özellikle psikoloji, sosyoloji ve tüketici davranışları alanında çalışan araştırmacılar için farklı yönleri ile incelenmeye çalışılmaktadır. Kompulsif satın alma, kompulsif tüketim davranışlarının bir parçası olarak görülmektedir. Amerikan Psikiatri Birliği'ne göre "kompulsiyon" belirli kurallara göre veya basmakalıp bir tarzda gerçekleştirilen, tekrarlayan ve görünüşte amaca yönelik davranışlar bütünüdür (O'Guinn ve Faber, 1989: 147). Duygusal olan ve çevresel faktörlerden nispeten daha kolay etkilenen bireylerde kompulsif davranış daha sık görülmektedir. Kompulsif davranış, genellikle sıkıntılı durumlardan kurtulmanın, baskılardan uzaklaşmanın veya problemlerin göz ardı edilmesi noktasında ortaya çıkmaktadır (Faber ve O'Guinn, 1988: 100). Kumar, aşırı alkol ve sigara kullanımı, obeziteye yol açacak şekilde aşırı yemek, aşırı ve dürtüsel şekilde alışveriş yapmak gibi çeşitli kompulsif davranışlar bireylerin fiziksel ve psikolojik olarak sağlıklarını olumsuz yönde etkilerken, ekonomik olarak da çok büyük zararlar vermektedir.

Kompulsif tüketim içerisinde önemli bir yer teşkil eden kompulsif satın alma davranışını sergileyen bireyler, yaptıkları alışverişlerde plansız, spontane olarak karar veren ve harcamalarının miktarını ve parasal ölçüsünü hesap etmekte güçlük çeken kişiler olarak tanımlanmaktadırlar (Dittmar, 2004: 414). Kinney vd., (2015) mobil uygulamalar ya da internet sitesi üzerinden alışveriş yapan üniversite öğrencileri üzerinde yaptıkları araştırmada, gün içerisinde sadece belirli zaman dilimlerini kapsayan alışveriş kampanyalarının, sosyal baskının kompuslif satın alma davranışını tetiklediğini ifade etmiştir. Bighiu vd., (2013) ise Romanya'da internet üzerinden alışveriş yapan bireyler arasında kredi kartı limitinin fazla olması, alışveriş sırasında 


\section{O. Karahan - C. Söylemez 11/3 (2019) 1961-1975}

kendilerini daha rahat hissederek mağaza ortamındaki bakışlardan uzak kalmaları sebebi ile kompulsif satın alma davranışını daha sık sergilediklerini belirtmiştir. Alışveriş sonrası yaşanan mutluluk ve haz duygusunun kısa süre sonra kızgınlık ve pişmanlık duyguları ile yer değiştirdiğini ifade etmiştir. Roberts vd., (2019) Amerika'da üniversite öğrencileri üzerinde yaptıkları araştırmalarda aile içi çatışmaların yaşandığı durumlarda, genç bireylerde kompulsif satın alma davranışının daha sık görüldüğünü, materyalizm ve özsaygı kavramlarının da anlamlı derecede bu davranışla ilişkili olduğunu belirtmişlerdir. Yapılan çalışmalarda bu tür kişilerin, kontrol edilemez dürtülere sahip oldukları, ihtiyaç bile duymadıkları ürünleri satın aldıkları, kendilerini çoğu zaman endişeli, gergin ve mutsuz hissettikleri ancak alışveriş esnasında tüm bu karakteristik özelliklerini unutarak geçici mutluluk yaşadıkları ve özsaygılarının düşük olduğu belirtilmiştir (Faber ve Christenson, 1996: 813; Müller vd., 2014: 106; Villardefrancos vd., 2016: 132; Moulding vd., 2017: 8). Kompulsif satın alma davranışı ile bu davranışı sergileyen bireylerin demografik özellikleri ile ilgili çalışmalara bakıldığında; bu bireylerin nispeten genç yaşta oldukları, çoğunluğunu kadınların oluşturdukları ve beklenilenin aksine belirli bir gelir grubu dilimi içerisinde yer almadıkları ifade edilmiştir (O'Guinn ve Faber, 1989; d'Astous, 1990; Scherhorn vd., 1990; Ergin, 2010; Lee ve Workman, 2015; Inseng ve Teichert, 2016). Bu çalışmaların aksine kompulsif satın alma davranışı ile demografik özellikler arasında anlamlı bir ilişkinin olmadığını ifade eden araştırmalar da mevcuttur (Park ve Choi, 2013; Pandey, 2016; De Mattos vd., 2016).

Literatürde kompulsif satın alma davranışını sergileyen bireylerin karakteristik ve demografik özellikleri dışında parasal tutumları, kredi kartı kullanma durumları da incelenmiştir. Yapılan araştırmalarda bireylerin parasal gücü çok önemsedikleri, prestij ve statü simgesi olarak gördükleri ve kredi kartı limitlerini sonuna kadar kullandıkları belirtilmiştir (Phau ve Woo, 2008; Roberts ve Jones, 2001; Joieramn vd., 2010). Farklı kültüre sahip ülkelerde yaşayan bireylerin kompulsif satın alma davranışı eğilimlerinin karşılaştırıldığı araştırmalarda da şaşırtıcı şekilde Hindistan, Çin, Tayland gibi ülkelerin; İngiltere, Almanya, Amerika gibi ülkelere kıyasla daha yüksek orana sahip oldukları görülmüştür (Mueller vd., 2007; Lo ve Thomson, 2012).

\subsection{Kompulsif Satın Alma Davranışını Etkileyen Faktörler}

Sosyoloji, din, felsefe bilimi çalışmaları dışında, özellikle son yıllarda pazarlama biliminin tüketici davranışları alanında materyalizm ile ilgili çalışmaların gelişim gösterdiği görülmektedir. İçinde yaşadığımız çağın "tüketim toplumu" olarak adlandırılması, Z kuşağı olarak adlandırılan yeni neslin post-modern pazarlama uygulamaları ile kendilerini özdeşleştirmeleri, çevrimiçi alışveriş platformlarının gelişmesi ve sosyal mecralarda rol model olarak görülen ünlülerin kullandıkları ürün ve markaları, statü ve güç simgesi olarak tanitmaları bu gelişmelere sebebiyet vermektedir.

Materyalizm kavramı, bireylerin kendilerine ait olan varlıkları hayatlarının merkezine koyarak; bu varlıkları statü ve mutluluk sembolü haline getirmeleri inancını ifade etmektedir (Chan ve Prendergast, 2007: 214). Materyalizmin bir kişilik özelliği olduğunu iddia eden Belk'e (1985) göre imrenme, sahip olma arzusu ve cömert olmama unsurları materyalizmin alt boyutlarını oluşturmaktadır. İmrenme olarak adlandırılan unsur, başkalarının sahip olduğu varlıkların kendisinde olma isteği iken, sahip olma arzusu ise sürekli olarak elde tutulan maddi varlıkların artırılma ya da elde tutulması arzusunu ifade etmektedir. Son olarak, cömert olmama unsuru da, bireylerin sosyal çevresi ile maddi varlıklarını paylaşmaması olarak tanımlanmaktadır (Belk, 1985). Richins ve Dawson'a (1992) göre ise, materyalizm bireyin hayatında merkeze koyduğu varlıklara atfettiği önem derecesini ve inançlarını yansıtmaktadır ve üç alt boyuttan oluşmaktadır. Sahip olma merkeziyetçiliği olarak ifade ettiği ilk boyut, bireylerin sahip oldukları varlıkları hayatlarının merkezine koyma durumunu gösterirken, tüketme eylemi adeta yaşama amaçları haline gelmektedir. Mutluluk arayışı olarak sahip olma boyutu, bireylerin satın aldıkları ve edindikleri her yeni varlıkta mutluluğa ve tatmin duygusuna yaklaştıkları inancını ifade etmektedir. Son boyut olan başarı ise, bireylerin sahip olduklarının sayıları ve maddi değerlerine göre kendilerini veya çevresindekileri değerlendirme ölçütüdür. Son olarak Richins ve Rudmin (1994), materyalizm kavramını sahip olunan tüm değerlerden veya kişisel özelliklerden daha fazla tüketim ile benzersiz bir şekilde tanımlanması gerektiğini iddia etmişlerdir.

Literatüre bakıldığında materyalizm kavramı, araştırmacılar tarafından farklı bakış açıları ile ifade edilmeye çalışılsa da, araştırmaların ortak noktası kompulsif satın alma davranışı ile ilişkilendirilmesidir. Donnelly vd., (2013) yaptıkları çalışmada, materyalizm düzeyi yüksek olan bireylerin kredi yükümlülüklerini yerine getiremediklerini, kompulsif satın alma davranışı içerisinde oldukları için satın aldıkları varlıkların 


\section{O. Karahan - C. Söylemez 11/3 (2019) 1961-1975}

hayatlarını değiştireceklerine inandıklarını ifade etmiştir. Dittmar (2005), kompulsif satın alma eylemini gerçekleştiren bireylerin materyalizm seviyelerinin yüksek olduğunu ifade ederken; Mowen ve Spears (1999), Amerika' da üniversite öğrencileri üzerinde yaptıkları araştırmada, materyalizmin üniversite nüfusu içindeki kompulsif satın alma seviyelerindeki varyansın \% 28'ini oluşturduğunu ifade etmiştir. Dean ve Yang (2007), Goldberg vd., (2003), Hanley ve Wilhelm (1992) yaptıkları araştırmalarda materyalizm ve/ veya materyalistik değerler ile kompulsif satın alma davranışı arasında anlamlı ilişki olduğunu ifade etmişlerdir. Zerach (2015) ise, İsrail'de gerçekleştirdiği araştırmasında materyalizm ile kompulsif satın alma davranışı arasında daha önceki çalışmaların aksine negatif yönlü bir ilişki olduğunu belirtmiştir. Dolayısıyla ele alınan bu çalışmada da materyalizm ve kompulsif satın alma davranışı arasındaki hipotezde aşağıdaki şekilde oluşturulmuştur.

Hipotez 1: Materyalizm, kompulsif satın alma davranışını pozitif yönde etkilemektedir.

Akran etkisi, sosyal psikoloji ve tüketici davranışları alanlarında sıklıkla kullanılmakta, araştırmacılara bireylerin davranışlarını inceleme ve önceden tahmin etmede yardımcı olmaktadır. Planlı davranış Teorisi içerisinde subjektif norm ve/veya etik teorilerinde referans grup olarak adlandırılan kavramlar, kompulsif satın alma ile ilgili yapılan çalışmalarda akran etkisi olarak ifade edilmektedir. Akranları ile düzenli şekilde iletişim içerisinde olan gençlerin, düzenli iletişime sahip olmayan gençlere göre akran etkisinde kalma ve akranlarının baskılarına boyun eğme eğiliminin daha fazla olduğu farklı çalışmalarda ortaya çıkmıştır (Achenreiner ve John, 2003; Benmoyal-Bouzaglo ve Moschis, 2010). İslam vd., (2017) Pakistan'da üniversite öğrencileri üzerinde yaptıkları araştırmada akran etkisinin materyalizm faktörünü ve dolaylı olarak da kompulsif satın alma davranışına etki ettiğini ifade etmişlerdir. Wang ve Xiao (2009), üniversite öğrencilerinin kredi kartı kullanımı ve satın alma kalıpları ile ilgili yaptıkları araştırmada akran etkisi altında olan öğrencilerin kompulsif satın alma davranışını daha sık sergilediklerini ve buna bağlı olarak da kredi kartı limitlerini zorladıklarını belirtmişlerdir. Luo (2005) tarafından yapılan araştırmada ise, akran etkisinin kompulsif satın alma davranışını pozitif yönlü bir şekilde etkilediği tespit edilirken; aile üyelerinin etkisinin ise negatif olduğu belirtilmiştir. Akranların, arkadaş grubuna katılım, seçimleri hakkında onay alma ve sosyalleşme gibi sebepler yüzünden etkisinin, diğer çevresel ve durumsal faktörlere göre daha yüksek olduğu ifade edilmiştir. Literatürdeki araştırmalara dayanarak çalışmada yer alan akran etkisi faktörü ile ilgili hipotez aşağıdaki şekildedir:

Hipotez 2: Akran etkisi, kompulsif satın alma davranışını olumlu yönde etkilemektedir.

Özsaygı, bireyin kendi kendini değerlendirmesi (onaylaması veya onaylamaması) ve değerlendirme sonucuna göre de kendisinin değerli olup olmadığına inanması anlamına gelir (DeSarbo ve Edwards, 1996: 236). Başka bir tanıma göre ise, bireyin kendini değerli veya yeterli bir insan olarak görme ve kabul etmesine ilişkin duygularının bütünüdür (Eryılmaz ve Atak, 2011: 172). Genellikle özsaygısı yüksek olan bireylerin, depresyona girme veya ruhsal dalgalanmalar gibi duygusal problemler yaşama olasılığı düşükken; belirsizlik durumunda veya zorluklarla mücadele noktasında da özsaygısı düşük olan bireylere göre daha başarılı olduğu görülmüştür (Palan vd., 2011: 84). Dolayısıyla kompulsif satın alma ile ilgili çalışmaların çoğunluğu düşük özsaygı kavramı ile ilgilidir (Faber ve O'Guinn, 1988; D' Astous, 1990; Yurchisin ve Johnson, 2004; Black, 2010; Davenport vd., 2014; Lee vd., 2016; Noh ve Hasan, 2017).

Literatüre bakıldığında, kompulsif satın alma eğilimi gösteren bireylerin düşük özsaygı düzeyine sahip oldukları, fazlaca hayal kurdukları, kredi kartlarını sıklıkla kullandıkları ve ödeme güçlügü çektikleri görülmüştür (O'Guinn ve Faber, 1989; Maltais ve Roberge, 1990; Scherhorn vd., 1990; Christenson vd., 1992; Omar vd., 2013; Moon vd., 2015). Literatürdeki bu çalışmalara bağlı olarak araştırma kapsamında oluşturulan hipotez aşağıdaki gibidir:

Hipotez 3: Özsaygı, kompulsif satın alma davranışın olumsuz yönde etkilemektedir.

Pişmanlık üzerine yapılan ilk çalışmalar psikoloji bilimine dayanmaktayken; ilerleyen süreç içerisinde araştırmacılar tarafından sosyoloji, felsefe, örgütsel davranış, tüketici davranışları gibi farklı alanlarda da gerçekleştirilmiştir. Pişmanlık bireyler için talihsizlikler, kayıplar, hatalar vb. için acı ve üzüntü verici durum olarak adlandırılmaktadır (Landman, 1993: 27). Bazı araştırmacılar, pişmanlık kavramının seçilen ya da seçilmeyenin karşılaştırılmasından sonra sonuç olarak ortaya çıktığını savunurken (Zeelenberg ve Pieters, 2007; Lee ve Cotte, 2009); Connolly vd. (2006) ise karar verme sürecinin niteliğine bağlı olarak da bireylerin pişman olabileceğini belirtmiştir. Bireylerin hissettikleri pişmanlık duygusunun yoğunluğu, karşılaştıkları 
durumun özelliklerine ve bireylerin karakterlerine göre değişiklik göstermektedir (Delacroix, 2003: 136).Bireylerde ortaya çıkan pişmanlık duygusunun sebeplerini araştıran Tsiros and Mittal (2000) ise, durumsal faktörleri değerlik (Valans), algılanan sorumluluk, verilen kararın haklılığı, zamanlaması ve alternatif seçeneklerin sayısı olarak sıralamaştır. Bireylerin kişilik özelliklerine bağlı olarak pişmanlık duygusunun değişiklik göstermesini ise öz saygı, riskten kaçınma, sosyal karşılaştırma eğilimi, iyimserlik kötümserlik ve ağır hareket etme unsurları ile açıklamıştır.

Tüketici davranışları içerisinde satın alma davranışı sonrası pişmanlık faktörünün ilk incelemesi (Oliver, 1997) tarafından gerçekleştirilmiştir. Bu araştırmaya göre birey, gerçekleştirdiği satın alma davranışından tatmin olmadığı durumlarda geriye dönük pişmanlık ve mutsuzluk yaşamaktadır. Kompulsif satın alma davranışını inceleyen araştırmacılar ise farklı bakış açılarıyla bu faktörü incelemeye devam etmişlerdir. Bushra ve Bilal (2014) Pakistan'da üniversite öğrencileri üzerinde yaptıkları araştırmada kompulsif satın alma davranışı gösteren öğrencilerin satın alma sonrası pişmanlık sergilediklerini belirtmişlerdir. Aynı şekilde Faber ve Vohs (2004), Mcelroy vd., (1994) kompulsif satın alma davranışı gösteren bireylerin duygularını inceledikleri araştırmalarında utanç, şüphe, umutsuzluk ve pişmanlık ile karşılaştıklarını ifade etmişlerdir. Dolayısıyla ele alınan bu araştırma kapsamında kompulsif satın alma ve alışveriş sonrası pişmanlık arasındaki ilişkiyi test etmek için aşağıdaki hipotez oluşturulmuştur.

Hipotez 4: Kompulsif satın alma davranışı ile satın alma sonrası pişmanlık arasında pozitif yönlü bir ilişki vardır.

\section{Metodoloji}

\subsection{Araştırmanın Amact}

Araştırmanın amacı, tüketicilerin kompulsif satın alma davranışlarının belirlenmesi, kompulsif satın alma davranışı üzerinde materyalizm, özsaygı ve akran etkisinin olup olmadığını tespit etmektir. Ayrıca bireylerin kompulsif satın alma davranışlarının satın alma eylemi sonrası ortaya çıkan pişmanlık (satın alma sonrası pişmanlık) davranışı üzerinde etkisinin ortaya konulması da araştırma kapsamında incelenecek konulardan biridir.

\subsection{Araştırmanın Modeli}

Araştırmanın amacına uygun şekilde oluşturulan modelde kompulsif satın alma, materyalizm, özsaygı, akran etkisi ve satın alma sonrası değişkenleri yer almaktadır. Oluşturulan araştırma modeli, tüketicilerin kompulsif satın almaya karşı bakış açılarının ortaya konması ve satın alma eylemi sonrası ortaya çıkabilecek olan pişmanlık duygusunun tahmin edilmesi amacına dayanmaktadır. Araştırma modelinde yer alan değişkenler ve bu değişkenler arasındaki ilişki ilgili literatür dikkate alınarak oluşturulmuştur. Araştırma modeli Şekil 1 'de gösterilmektedir.

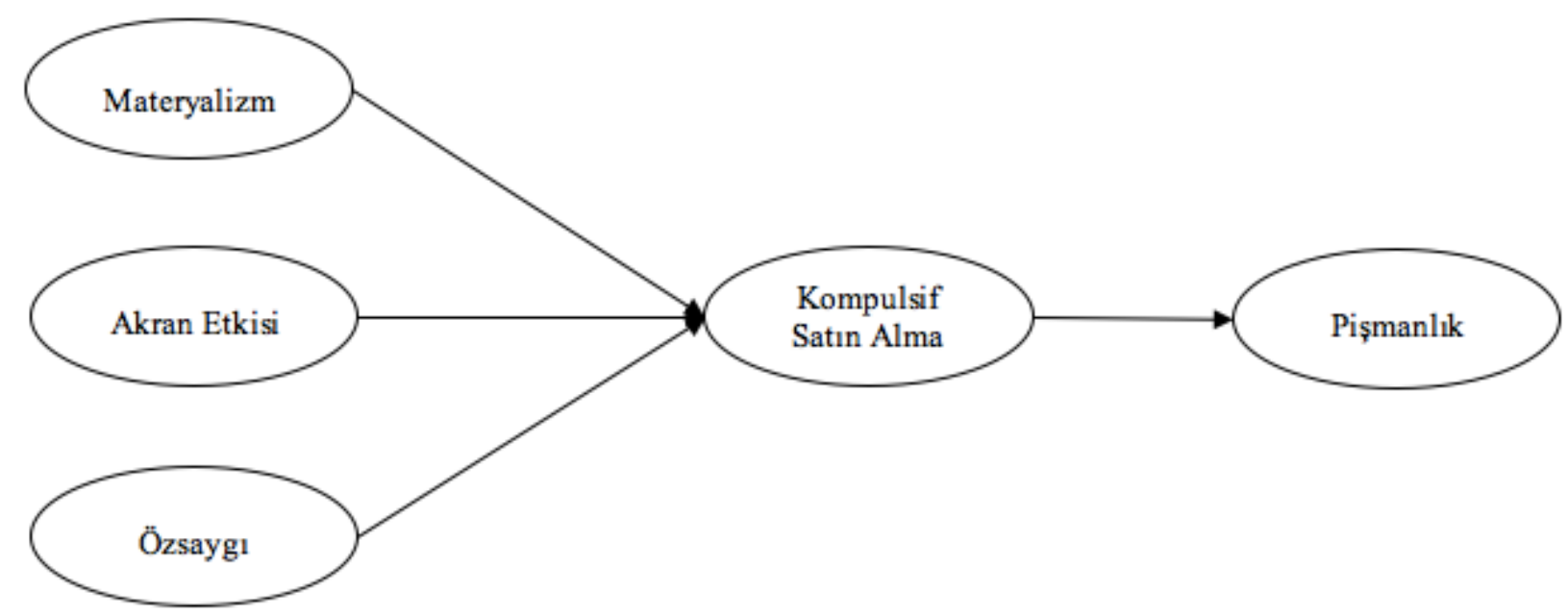

Şekil 1. Araştırma Modeli 


\subsection{Araştırmanın Anakütlesi, Örneklem ve Verilerin Toplanması}

Araştırmanın evrenini 18 yaşından büyük tüketiciler oluşturmaktadır. Ancak 18 yaşından büyük bireylerin oluşturduğu anakütlenin büyüklüğü değerlendirildiğinde evrenin tamamına ulaşmanın mümkün olmadığ1 anlaşılmaktadır. Anakütlenin çok büyük olduğu durumlarda kolayda örnekleme yöntemi kullanılabilmektedir (Nakip, 2003: 183). Bu nedenle araştırma kapsamında elde edilen verilerin toplanmasında kolayda örnekleme yöntemi kullanılmıştır.

Veri toplama amacıyla hazırlanan form online ve yüzyüze anketlerle tüketicilere uygulanmıştır. Bu kapsamda 15.12.2018-30.05.2019 tarihleri arasında toplamda 376 tüketiciden veri toplanmıştır. Cevaplama kaynaklı problemler, eksik veri nedeniyle 35 anket veri setinden çıkartılmış ve kalan 341 veri ile araştırmanın analizleri gerçekleştirilmiştir. Elde edilen bu örneklem büyüklügü yapısal eşitlik modellemesi için yeterli büyüklüktedir (Kline, 2011:11-12). Beşli likert (1-Kesinlikle Katılıyorum, 5-Kesinlikle Katılmıyorum) tipinde hazırlanan veri seti, Lisrel 8.1 ve SPSS 21.0 paket programları kullanılarak analiz edilmiştir.

Araştırma modeli kapsamında öne sürülen araştırma değişkenlerinden kompulsif satın almaya ilişkin 7 ifade Faber ve O'Guinn'in (1992), akran etkisine ait 3 ifade Mangleburg ve Bristol'un (1998), materyalizme ait 6 ifade Richins ve Dawson'ın (1992), özsaygıya yönelik 3 ifade Rosenberg'in (1965) ve satın alma sonrası pişmanlığa yönelik 3 ifade Tsiros ve Mittal'in (2000) çalışmalarından uyarlanarak araştırmaya dahil edilmiştir.

\section{Araştırmanın Bulguları}

\subsection{Tanımlayıcı İstatistiki Bulgular}

Araştırmaya katılan bireylerin cinsiyet, yaş, eğitim düzeyi ve gelir duruma yönelik elde edilen bulgular Tablo 1 'de sunulmaktadir.

Tablo 1. Katılımcıların Demografik Özellikleri

\begin{tabular}{llcc}
\hline Demografik Özellikler & & Frekans & \% \\
\hline \multirow{2}{*}{ Cinsiyet } & Kadın & 175 & 51,3 \\
\cline { 2 - 4 } & Erkek & 166 & 48,7 \\
\hline \multirow{3}{*}{ Yaş } & $18-30$ & 239 & 70,1 \\
\cline { 2 - 4 } & $31-44$ & 80 & 23,5 \\
\cline { 2 - 4 } & 45 ve üzeri & 22 & 6,4 \\
\hline \multirow{5}{*}{ Eğitim Düzeyi } & İköğretim & 5 & 1,5 \\
\cline { 2 - 4 } & Lise & 4 & 2,9 \\
\cline { 2 - 4 } & Önlisans & 266 & 1,2 \\
\cline { 2 - 4 } & Lisans & 56 & 78,0 \\
\cline { 2 - 4 } Aylik Gelir Düzeyi & Lisansüstü & 106 & 27,6 \\
\hline & 2020 TL ve altı & 69 & 31,1 \\
\cline { 2 - 4 } & 2021-3600 TL & 72 & 20,2 \\
\cline { 2 - 4 } & 3601-4800 TL & $\mathbf{3 4 1}$ & $\mathbf{1 0 0}$ \\
\cline { 2 - 4 } & 4801 TL ve üzeri & & \\
\hline
\end{tabular}

Tablo 1'e göre, araştırmaya katılan bireylerin yaklaşık \%51'i kadın ve \%49'u erkeklerden oluşmaktadır. Katılımcıların çoğunluğu (yaklaşık \%70) 18-30 yaş aralığında yer almaktadır. Eğitim düzeylerine bakıldığında ise 266 katılımcının lisans, 56 katılımcının yüksek lisans mezunu olduğu anlaşılmaktadır. Araştırmaya katılım sağlayan bireylerin gelir düzeylerine bakıldığında \%27,6'sının asgari ücret ve altında, \%31,1'inin ise 2021-3600 TL arasında gelire sahip olduğu elde edilen bulgular arasındadır.

\subsection{Yorumlayıcı İstatistiki Bulgular}

\subsubsection{Açımlayıcı Faktör Analizi (AFA) Bulguları}

Açımlayıcı faktör analizi, değişkenleri özet bir biçimde göstermeye yarayan çok değişkenli bir analiz yöntemi olarak kullanılmaktadır. Açımlayıcı faktör analizinde veri setinin faktör analizine uygunluğunu test etmek için KMO (Kaiser-Meyer-Olkin) testi ve Bartlett's Sphericity küresellik testleri kullanılmaktadır (Punch, 2005: 
M. O. Karahan - C. Söylemez 11/3 (2019) 1961-1975

124; Kalaycı, 2010:322). Bu kapsamda araştırma modelinde yer alan kompulsif satın alma yapısını oluşturan 7 madde, materyalizm yapısını oluşturan 6 madde, özsaygı yapısını oluşturan 3 madde, akran etkisini oluşturan 3 madde ve satın alma sonrası pişmanlık yapısını oluşturan 3 madde için temel bileşenler analizi ve varimax döndürme yöntemi kullanılarak faktör analizi yapılmıştır. Açımlayıcı faktör analizi sonuçları Tablo 2'de gösterilmektedir.

Tablo 2. Açımlayıcı Faktör Analizi Sonucu

\begin{tabular}{|c|c|c|c|c|c|}
\hline Değişkenler & Ortalama & S. Sapma & Faktör Yükü & Özdeğer & $\alpha$ \\
\hline \multicolumn{6}{|l|}{ Materyalizm } \\
\hline M2 & 3,94 & 1,110 & 0,689 & \multirow{4}{*}{1,505} & \multirow{4}{*}{0,791} \\
\hline M3 & 3,33 & 1,204 & 0,857 & & \\
\hline M4 & 3,14 & 1,164 & 0,591 & & \\
\hline M5 & 2,63 & 1,260 & 0,763 & & \\
\hline \multicolumn{6}{|c|}{ Kompulsif Satın Alma } \\
\hline KS1 & 2,48 & 1,185 & 0,582 & \multirow{7}{*}{6,046} & \multirow{7}{*}{0,832} \\
\hline KS2 & 1,94 & 1,174 & 0,571 & & \\
\hline KS3 & 3,13 & 1,309 & 0,617 & & \\
\hline KS4 & 2,06 & 1,156 & 0,748 & & \\
\hline KS5 & 2,37 & 1,272 & 0,715 & & \\
\hline KS6 & 2,81 & 1,299 & 0,613 & & \\
\hline KS7 & 1,99 & 1,189 & 0,826 & & \\
\hline \multicolumn{6}{|l|}{ Akran Etkisi } \\
\hline A1 & 3,13 & 1,166 & 0,859 & \multirow{3}{*}{1,395} & \multirow{3}{*}{0,807} \\
\hline $\mathrm{A} 2$ & 2,24 & 1,158 & 0,663 & & \\
\hline A3 & 3,10 & 1,203 & 0,855 & & \\
\hline \multicolumn{6}{|l|}{ Özsayg1 } \\
\hline $\mathrm{O} 1$ & 3,52 & 1,105 & 0,796 & \multirow{3}{*}{1,705} & \multirow{3}{*}{0,861} \\
\hline $\mathrm{O} 2$ & 4,07 & 1,053 & 0,884 & & \\
\hline $\mathrm{O} 3$ & 3,97 & 1,122 & 0,869 & & \\
\hline \multicolumn{6}{|c|}{ Satınalma Sonrası Pişmanlık } \\
\hline P1 & 2,16 & 0,960 & 0,892 & \multirow{3}{*}{2,901} & \multirow{3}{*}{0,903} \\
\hline $\mathrm{P} 2$ & 2,05 & 0,990 & 0,878 & & \\
\hline $\mathrm{P3}$ & 2,29 & 1,071 & 0,826 & & \\
\hline
\end{tabular}

KMO Testi: 0,852

Barlett Sphericity Testi: 3353,795 df:190 Sig: 0,000

Tablo 2'de yer alan bilgilere göre, araştırmada kullanılan değişkenlerin KMO değeri \%0,85 ve Barlett's Sphericity testi değeri $\mathrm{p}<0,001$ 'dir. Bu nedenle veri setinin faktör analizine uygun olduğu ifade edilebilir. Açımlayıcı faktör analizi sonucunda materyalizme ait M1 ve M6 nolu ifadelerin faktör yükleri 0,50'nin altında kaldığı ve başka faktörlere çapraz yüklendiği için araştırmadan çıkarılarak diğer değişkenler üzerinden faktör analizi gerçekleştirilmiştir. Bu doğrultuda elde edilen veriler incelendiğinde; materyalizm faktörüne ait yüklerin 0,591-0,763 arasında, kompulsif satın alma faktörüne ait yüklerin 0,571-0,826 arasında, akran etkisi faktörüne ait yüklerin 0,663-0,859 arasında, özsaygı faktörüne ait yüklerin 0,796-0,884 arasında ve satın alma sonrası pişmanlık faktörüne ait yüklerin 0,826-0,892 arasında değerlere sahip olduğu anlaşılmaktadır. Araştırmada yer alan bu beş faktörün toplam varyansın \%67,76'sını açıkladığı elde edilen bulgular arasındadır. Faktörlerin güvenirlilik katsayılarına bakıldığında ise, her bir faktörün değerinin 0,70' den büyük olduğu ve dolayısıyla içsel tutarlığında sağlandığı ifade edilebilir (Hair vd., 2010). Diğer bir ifadeyle materyalizm değişkenine ait 4 ifadenin 0,791; kompulsid satın alma değişkenine ait 7 ifadenin 0,832; akran etkisi değişkenine ait 3 ifadenin 0,807; özsaygı değeşkenine ait 3 ifadenin 0,861 ve satın alma sonrası pişmanlık değişkenine ait 3 ifadenin güvenilirlik değerlerinin 0,903 olduğu sonucuna ulaşılmıştır. Kalaycı'ya (2010) göre elde edilen bu sonuçlar araştırma kapmasında kullanılan değişkenlerin oldukça güvenilir olduğunu ortaya koymaktadir. 


\subsubsection{Doğrulayıcı Faktör Analizi (DFA) Bulguları}

Açımlayıcı faktör analizinden sonra araştırma modelinin güvenirliğini ve geçerliliği test etmek amacıyla doğrulayıcı faktör analizi gerçekleştirilmiştir. Doğrulayıcı faktör analiziyle araştırma kapsamında elde edilen verilerle teorik olarak oluşturulan yapının doğrulanıp doğrulanmadığı analiz edilebilmektedir (Çokluk vd., 2016: 177). Şekil 2'de araştırma verilerine ilişkin doğrulayıcı faktör analizi diagramı sunulmaktadır.

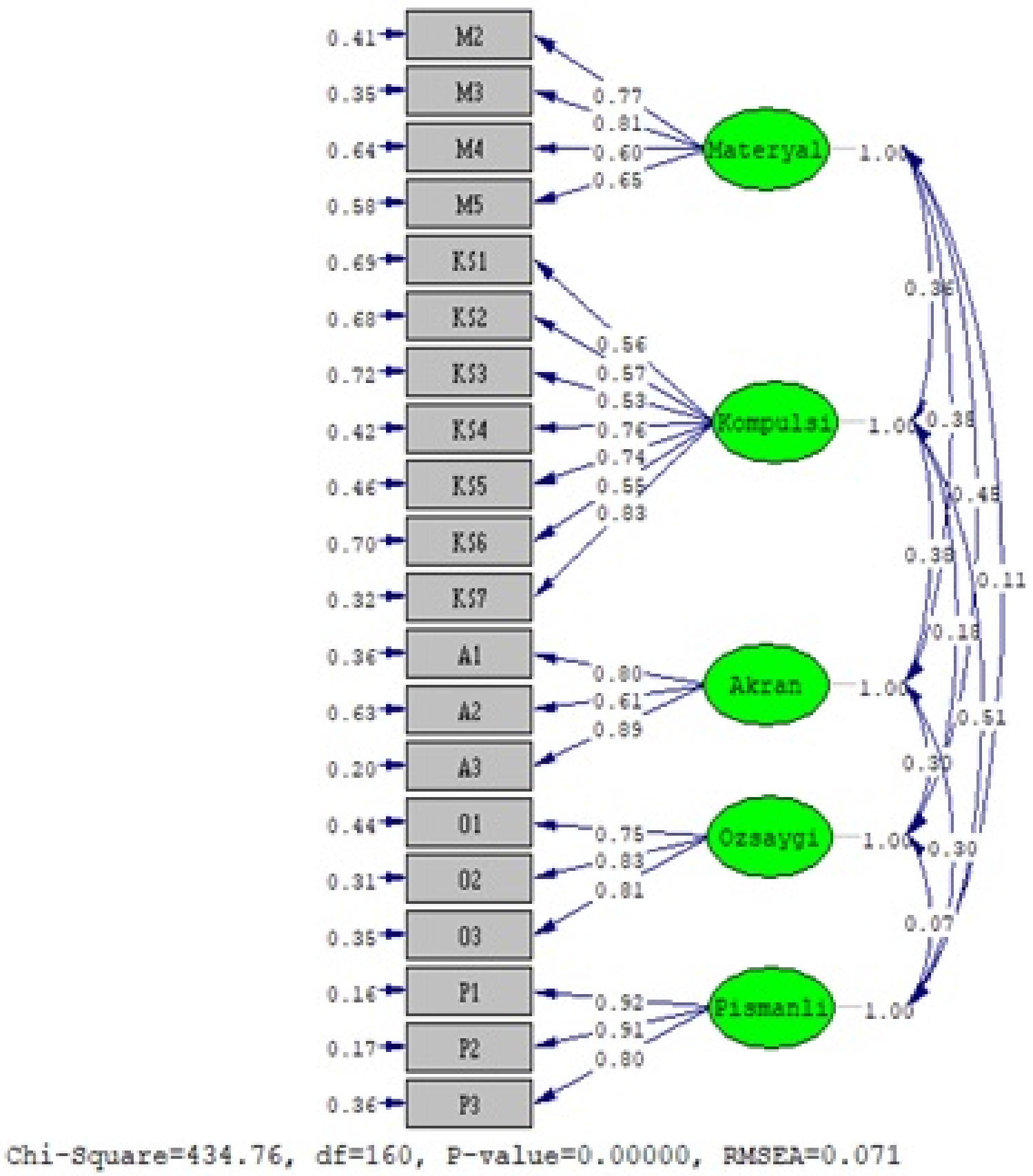

Şekil 2. Doğrulayıcı Faktör Analizi

Tablo 3'te ölçüm modeline ilişkin doğrulayıcı faktör analizi sonucunda elde edilen standardize edilmiş yol katsayıları (SEYK), t değerleri, yapı güvenirliliğ̈i (composite reliability-CR), ortalama açılanan varyans (average variance extracted-AVE) ve Cronbach's Alpha $(\alpha)$ değerleri gösterilmektedir. Araştırma için değişkenler arasındaki parametrelerin tahmininde Maximum Likelihood Estimation (en yüksek olabilirlik) yöntemi kullanılmıştır. 
M. O. Karahan - C. Söylemez 11/3 (2019) 1961-1975

Tablo 3. Doğrulayıcı Faktör Analizi Sonuçları

\begin{tabular}{|c|c|c|c|c|c|}
\hline Faktörler & SEYK & $t$ değeri & CR & AVE & Güvenilirlik \\
\hline \multicolumn{6}{|l|}{ Materyalizm } \\
\hline M2 & 0,77 & $15,25^{*}$ & \multirow{4}{*}{0,80} & \multirow{4}{*}{0,51} & \multirow{4}{*}{0,791} \\
\hline M3 & 0,81 & $16,27^{*}$ & & & \\
\hline M4 & 0,60 & $11,11^{*}$ & & & \\
\hline M5 & 0,65 & $12,29^{*}$ & & & \\
\hline \multicolumn{6}{|c|}{ Kompulsif Satın Alma } \\
\hline KS1 & 0,56 & $10,55^{*}$ & \multirow{7}{*}{0,80} & \multirow{7}{*}{0,44} & \multirow{7}{*}{0,832} \\
\hline KS2 & 0,57 & $10,75^{*}$ & & & \\
\hline KS3 & 0,53 & $9,81^{*}$ & & & \\
\hline KS4 & 0,76 & $15,76^{*}$ & & & \\
\hline KS5 & 0,74 & $15,01^{*}$ & & & \\
\hline KS6 & 0,55 & $10,27^{*}$ & & & \\
\hline KS7 & 0,53 & $17,69^{*}$ & & & \\
\hline \multicolumn{6}{|l|}{ Akran Etkisi } \\
\hline A1 & 0,80 & $16,01^{*}$ & \multirow{3}{*}{0,82} & \multirow{3}{*}{0,60} & \multirow{3}{*}{0,807} \\
\hline $\mathrm{A} 2$ & 0,61 & $11,60^{*}$ & & & \\
\hline $\mathrm{A} 3$ & 0,89 & $10,33^{*}$ & & & \\
\hline \multicolumn{6}{|l|}{ Özsayg1 } \\
\hline $\mathrm{O} 1$ & 0,75 & $14,89^{*}$ & \multirow{3}{*}{0,84} & \multirow{3}{*}{0,64} & \multirow{3}{*}{0,861} \\
\hline $\mathrm{O} 2$ & 0,83 & $17,01^{*}$ & & & \\
\hline $\mathrm{O} 3$ & 0,81 & $16,41^{*}$ & & & \\
\hline \multicolumn{6}{|c|}{ Satın Alma Sonrası Pişmanlık } \\
\hline P1 & 0,92 & $21,29^{*}$ & \multirow{3}{*}{0,91} & \multirow{3}{*}{0,77} & \multirow{3}{*}{0,903} \\
\hline $\mathrm{P} 2$ & 0,91 & $21,15^{*}$ & & & \\
\hline P3 & 0,80 & $17,42^{*}$ & & & \\
\hline
\end{tabular}

Ölçme modeline ilişkin olarak uyum geçerliliğinin sağlanabilmesi için ölçek maddelerinin standardize edilmiş faktör yüklerinin 0,70'in üzerinde olması istenmektedir (Kline, 2011). Tablo 3 incelendiğinde değişkenlere ilişkin standardize faktör yüklerinin çoğunluğunun 0,70 değerinden büyük olduğu görülmektedir. Yine yapısal eşitlik çalışmalarında kompozit geçerlilik değerinin 0,70 'den ve ortalama açıklanan varyans değerlerinin de 0,50'den büyük olması gerekmektedir (Hair vd., 2010). Tabloda Hair vd. (2010) önermiş olduğu formüle göre hesaplanan kompozit geçerlilik (CR) değerlerinin $0,70^{\prime}$ den ve ortalama açıklanan varyans (AVE) değerlerinin kompulsif satın alma değişkeni dışında 0,50' den büyük olduğu anlaşılmaktadır. Tabloda yer alan $\alpha$ güvenirlilik katsayıları da 0,70 değerinden büyüktür. Araştırma kapsamında elde edilen verilere göre, uyum geçerliliğinin sağlandığını ifade etmek mümkündür. Doğrulayıcı faktör analizinde bakılması gereken bir başka değer ise değişkenlere ilişkin $t$ değerlerinin anlamlılık düzeyleridir. Tablo'ya göre elde edilen $t$ değerlerinin Çokluk vd. (2016)'ya göre 0,01düzeyinde (2,56 değerinden büyük) manidar olduğu anlaşılmaktadır.

Ayırt edici geçerliliğin sağlanıp sağlanmadığını tespit amacıyla değişkenler arasındaki ilişkiyi temsil eden korelasyon matrisi ve AVE değerlerinin karekökleri Tablo 4'te gösterilmektedir. Tablo 4'te yer alan açıklanan varyans değerinin karekökü ile korelasyon katsayıları incelendiğinde ayırt edici geçerliliğin sağlandığı ifade edilebilir (Kline, 2011: 116). 
M. O. Karahan - C. Söylemez 11/3 (2019) 1961-1975

Tablo 4. Korelasyon Katsayıları ve Açıklanan Varyansların Karekök Değerleri

\begin{tabular}{llcccccc}
\hline & AVE $^{*}$ & $\mathbf{1}$ & $\mathbf{2}$ & $\mathbf{3}$ & $\mathbf{4}$ & $\mathbf{5}$ \\
\hline 1 & Materyalizm & 0,72 & 1 & & & & \\
\hline 2 & Kompulsif Satın Alma & 0,66 & 0,36 & 1 & & & \\
\hline 3 & Akran & 0,77 & 0,35 & 0,38 & 1 & & \\
\hline 4 & Özsayg1 & 0,80 & 0,45 & 0,18 & 0,30 & 1 & \\
\hline 5 & Pişmanlık & 0,87 & 0,11 & 0,51 & 0,30 & 0,07 & 1 \\
\hline${ }^{*}$ Açıklanan varyans değerinin karekökü & & & & & &
\end{tabular}

Doğrulayıcı faktör analizine ilişkin olarak ölçme modelinin uyum iyiliği değerlerine de bakılmıştır. Tablo 5'te doğrulayıcı faktör analizi uyum iyiliği değerleri gösterilmektedir. Elde edilen sonuçlara göre ölçme modelinin istatistiksel olarak anlamlı olduğu söylenebilir.

Tablo 5. DFA Uyum İyiliği Değerleri Sonucu

\begin{tabular}{lccc}
\hline Uyum İndeksi & $\begin{array}{c}\text { DFA Sonucu } \\
\text { Elde Edilen Değer }\end{array}$ & Sonuç & Kaynak \\
\hline$\chi^{2} / \mathrm{df}$ & 2,71 & Mükemmel Uyum & Kline, 2011; Çokluk vd., 2016 \\
\hline RMSEA & 0,071 & Kabul Edilebilir Uyum & Kline, 2011; Çokluk vd., 2016 \\
\hline GFI & 0,89 & Kabul Edilebilir Uyum & Kline, 2011; Çokluk vd., 2016 \\
\hline CFI & 0,96 & Mükemmel Uyum & Kline, 2011; Çokluk vd., 2016 \\
\hline NFI & 0,93 & Kabul Edilebilir Uyum & Kline, 2011; Çokluk vd., 2016 \\
\hline NNFI & 0,95 & Mükemmel Uyum & Kline, 2011; Çokluk vd., 2016 \\
\hline
\end{tabular}

\subsubsection{Yapısal Analiz ve Hipotez Testi Sonuçları}

Yapısal eşitlik modellemesi kapsamında araştırmaya ilişkin ölçme modeli doğrulandıktan sonra kuramsal olarak öne sürülen araştırma modelinin analizi ve hipotezlerin testine geçilmiştir. Yapısal modele ilişkin diagram Şekil 3'te sunulmaktadır.

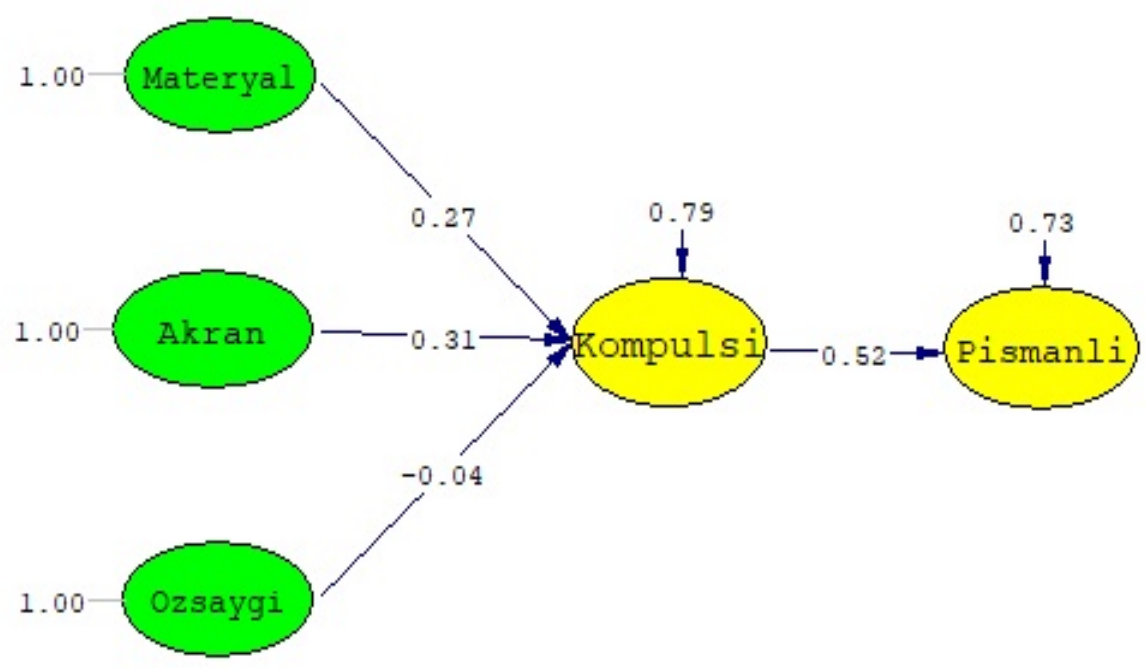

Chi-Square=440.45, df=163, P-value=0.00000, RMSEA=0.071

Şekil 3. Yapısal Modeline İlişkin Yol Analizi Sonucu

Gerçekleştirilen analiz sonucunda gizil değişkenlerin gözlenen değişkenleri açıklama durumlarına ilişkin $t$ değerlerinin anlamlı olduğu sonucuna ulaşılmıştır. Yine yapısal modelin uyum iyiliği değerlerinin literatürde istenen aralıklarda olduğu görülmektedir. Yapısal modelin uyum iyiliği değerlerine ilişkin detaylı bulgular Tablo 6'da yer almaktadır. 
M. O. Karahan - C. Söylemez 11/3 (2019) 1961-1975

Tablo 6. Yapısal Model Uyum İyiliği Değerleri

\begin{tabular}{lccl}
\hline Uyum İndeksi & $\begin{array}{c}\text { YEM Sonucu } \\
\text { Elde Edilen Değer }\end{array}$ & Sonuç & Kaynak \\
\hline$\chi^{2} / \mathrm{df}$ & 2,70 & Mükemmel Uyum & Kline, 2011; Çokluk vd., 2016 \\
\hline RMSEA & 0,071 & Kabul Edilebilir Uyum & Kline, 2011; Çokluk vd., 2016 \\
\hline GFI & 0,89 & Kabul Edilebilir Uyum & Kline, 2011; Çokluk vd., 2016 \\
\hline CFI & 0,96 & Mükemmel Uyum & Kline, 2011; Çokluk vd., 2016 \\
\hline NFI & 0,93 & Kabul Edilebilir Uyum & Kline, 2011; Çokluk vd., 2016 \\
\hline NNFI & 0,95 & Mükemmel Uyum & Kline, 2011; Çokluk vd., 2016 \\
\hline
\end{tabular}

Yapısal modelin uygunluğu kanıtlandıktan sonra, araştırma modelinde öngörülen nedensel ilişkileri ortaya koyabilmek ve araştırma hipotezlerini test edebilmek amacıyla standardize edilmiş yol katsayıları ve $t$ değerlerinden yararlanılmıştır. Tablo 7 'de araştırma modelinde öngörülen ilişkilere ait bulgular gösterilmektedir.

Tablo 7. Yol Analizi Sonuçları ve Hipotezler

\begin{tabular}{|c|c|c|c|}
\hline Hipotezler & $\begin{array}{c}\text { Standardize Edilmiş } \\
\text { Yol Katsayısı }\end{array}$ & $t$ değeri & $\mathbf{R}^{2}$ \\
\hline $\mathrm{H}_{1}:$ materyal $\rightarrow$ kompul & 0,27 & $3,52^{*}$ & \multirow{3}{*}{0,21} \\
\hline $\mathrm{H}_{2}$ : akran $\rightarrow$ kompul & 0,31 & $4,46^{*}$ & \\
\hline $\mathrm{H}_{3}$ : ozsaygi $\rightarrow$ kompul & $-0,04$ & $-0,56$ & \\
\hline $\mathrm{H}_{4}:$ kompul $\rightarrow$ pismanlik & 0,52 & $7,35^{*}$ & 0,27 \\
\hline
\end{tabular}

Tablo 7'de yer alan bulgulara göre; teorik araştırma modelinde öngörülenin aksine özsaygının kompulsif satın alma üzerindeki etkinin anlamsız (yol katsayısı: $-0,04$ ve p>0,05) çıktığı anlaşılmaktadır. Bu nedenle $\mathrm{H}_{3}$ hipotezi reddedilmiştir. Materyalizmin kompulsif satın alma ve akran etkisinin kompulsif satın alma üzerindeki etkisi $\mathrm{p}<0,01$ düzeyinde anlamlıdır. Yine kompulsif satın almanın satın alma sonrası pişmanlık üzerindeki etkisi de $\mathrm{p}<0,01$ düzeyinde anlamlı bulunmuştur. $\mathrm{Bu}$ nedenle $\mathrm{H}_{1}, \mathrm{H}_{2}$ ve $\mathrm{H}_{4}$ hipotezlerinin desteklendiği görülmektedir. Tablo 7 'de yer alan standardize edilmiş yol katsayıları incelendiğinde; materyalizm ve akran etkisinin kompulsif satın alma üzerindeki etki düzeyi orta, kompulsif satın almanın satın alma sonrası pişmanlık üzerindeki etkisi ise büyük olarak değerlendirilebilir (Kline, 2011: 185). Yine tabloya göre; materyalizm, akran etkisi ve özsayg1 kompulsif satın almanın \%21'ini ( $\left.\mathrm{R}^{2}\right)$; kompulsif satın alma da satın alma sonrası pişmanlık davranışının \%27'sini $\left(R^{2}\right)$ açılamaktadır.

Araştırma kapsamında öne sürülen modele ilişkin elde edilen bulgular araştırmaya dahil olan bireylerin sahip oldukları materyalist düşüncelerin ve çevrelerinde yer alan akranlarının kompulsif satın alma davranışı üzerinde etkili olduğunu ortaya koymaktadır. Kompulsif satın alma ile satın alma sonrası pişmanlık arasındaki ilişki incelendiğinde de araştırmaya katılan tüketicilerin satın alma sonrasında yapmış oldukları seçimin sonucunda gereksiz harcama yaptıkları düşüncesini hissettiklerini göstermektedir. Bu doğrultuda araştırma kapsamında elde edilen sonuçların literatürle (Hanley ve Wilhelm, 1992; Mowen ve Spears, 1999; Goldberg vd., 2003; Luo, 2005; Dean ve Yang, 2007; Wang ve Xiao, 2009; Donnelly vd., 2013; İslam vd., 2017) benzerlik gösterdiği söylenebilir. Ayrıca elde edilen sonuçlara göre; araştırmaya katılan tüketicilerin kontrolsüz ve aşırı bir şekilde alışveriş yaptıkları, materyalizm seviyelerinin yüksek olduğu, kompulsif alışveriş davranışlarında referans gruplarının etkisi altında kaldığını, düşük özsaygı düzeyine sahip oldukları ifade edilebilir.

\section{Sonuç}

Tüketici davranışı alanında çalışan araştırmacılar, genellikle tüketicilerin satın alma davranışı sergilerken rasyonel hareket etmemelerinin arkasında yatan sebepler üzerinde durmaktadırlar. Kompulsif satın alma davranışı da rasyonel olmayan tüketici davranışlarının başlıcalarındandır. Araştırmamız sonucunda, literatürde yer alan daha önceki çalışmaların aksine (Faber ve O'Guinn, 1988; D'Astous, 1990; Yurchisin ve Johnson, 2004) özsaygı değişkeninin kompulsif satın alma davranışına anlamlı bir etkisinin olmadığının görülmesi ilgi çekicidir. Materyalizm değişkeni ile kompulsif satın alma davranışı arasında beklenildiği gibi 


\section{O. Karahan - C. Söylemez 11/3 (2019) 1961-1975}

pozitif ve güçlü bir ilişkinin olduğu görülmektedir. Dean ve Yang (2007), Goldberg vd., (2003), Hanley ve Wilhelm (1992) gibi araştırmacılar tarafından benzer sonucun ortaya konulduğu görülmektedir. Akran etkisi değişkeninin de kompulsif satın alma davranışı üzerinde, daha önceki çalışmalara benzer şekilde (Wang ve Xiao, 2009; Luo, 2005; Benmoyal-Bouzaglo ve Moschis, 2010) anlamlı ve pozitif olduğu belirlenmiştir. Dolayısıyla, tüketiciler kompulsif satın alma davranışı sergilerken, çevresindeki bireylerin görüş, öneri veya baskıları doğrultusunda hareket etmektedirler. Son olarak, araştırmamızda kompulsif satın alma davranışı gösteren tüketicilerin, satın alma sonrasında ise pişmalık hissine kapıldıkları görülmektedir. Faber ve Vohs (2004), Mcelroy vd. (1994) ve Oliver (1997) yaptıkları çalışmalarında, benzer şekilde kompulsif satın alma davranışı sergileyen tüketicilerin, kısa süre sonra üzüntü, kızgınlık ve pişmanlık duygularına kapıldıklarını ifade etmişlerdir.

Materyalizm, bireylerin kendilerini ifade ederken sahip oldukları maddi değer ve statü kavramlarını hayatlarının merkezine alma isteklerini ifade etmektedir. Dolayısıla ülkemizde kompulsif satın alma davranışı sergileyen bireylerin, satın alma eylemini gerçekleştirirken kendilerini daha fazla değerli hissetme ve statülerini artırmaya çalıştıkları görülmektedir. İşletmelerin, pazarlama etiği gereğince tüketicileri ile olan pazarlama iletişimi sürecinde tüketicilerin bu hassasiyetlerini göz önünde bulundurmaları ve dikkate almaları gerekmektedir.

Araştırmada yer alan akran etkisinin kompulsif satın alma davranışı üzerinde etkili olması, bireylerin sosyal baskı ya da referans grup olarak adlandırılan çevreleri tarafından kolayca yönlendirilebildiğini göstermektedir. Ülkemizde yaşayan ve çoğunluğunu öğrencilerin oluşturduğu genç nüfus dikkate alındığında, okullarda tüketici bilincini artırmaya yönelik derslerin verilmesi, bilinçli ve sorumluluk sahibi bireylerin yetişmesi için gereklidir. Ülke genelinde kamu spotu reklamları ile kompulsif satın alma davranışının zararlarının yansıtılması toplumun bilinçlendirillmesi ve akran etkisinin olumsuz etkisinin kırılması için önemlidir.

Literatüre ve uygulamacılara katkı sağlamanın yanında araştırmanın bazı kısıtları bulunmaktadır. Öncelikle araştırma kapsamında elde edilen veriler kolayda örnekleme yöntemiyle toplandığı için ortaya konulan sonuçların genelleme yapılarak değerlendirilmesi mümkün olmamaktadır. İkinci olarak, zaman ve maliyet açısından çok sayıda tüketici bulunmasından dolayı evrene ilişkin bir çerçevenin olmaması da araştırmanın ikinci kısıtını oluşturmaktadır. Gelecekte yapılacak araştırmalarda, kompulsif satın alma üzerinde etkisi olduğu düşünülen farklı unsurların araştırılması (Marka değeri, alışverişe etki eden durumsal faktörler v.b.) ve farklı örneklem grupları ile çalışmalar yapılmalıdır. Yine farklı örneklem grupları (cinsiyet, ülke vb.) açısından kompulsif satın alma davranışının karşılaştırılmalı olarak incelenmesi literatüre katkı sağlama noktasında farklılıkların ortaya konulması için önemli olarak değerlendirilebilir.

\section{Kaynakça}

Achenreiner, G. B. (1997). Materialistic values and susceptibility to influence in children. Advances in Consumer Research, 24(1), 82-88.

Belk, Russell W. (1985). Materialism: Trait aspects of living in the material world, Journal of Consumer Research, 12 (December).

Benmoyal-Bouzaglo, S. and Moschis, G. P. (2010). Effects of family structure and socialization on materialism: A life course study in France. Journal of Marketing Theory and Practice, 18(1), 53-70.

Bighiu, G., Manolică, A., \& Roman, C. T. (2015). Compulsive buying behavior on the internet. Procedia Economics and Finance, 20, 72-79.

Black, D. W. (2010). Compulsive buying: clinical aspects. Impulse Control Disorders, 5-22.

Bushra, A. and Bilal, A. (2014). The relationship of compulsive buying with consumer culture and postpurchase regret. Pakistan Journal of Commerce and Social Sciences (PJCSS), 8(3), 590-611.

Chan, K. and Prendergast, G. (2007). Materialism and social comparison among adolescents, Social Behavior and Personality, 35 (2), 213-228.

Connolly, T. and Butler, D. (2006). Regret in economic and psychological theories of choice. Journal of Behavioral Decision Making, 19(2), 139-154. 


\section{O. Karahan - C. Söylemez 11/3 (2019) 1961-1975}

Çokluk, Ö., Şekercioğlu, G. ve Büyüköztürk, Ş. (2016). Sosyal Bilimler İçin Çok Değişkenli İstatistik SPSS ve LISREL Uygulamaları, 4. Baskı, Ankara, Pegem Akademi Yayınları.

Davenport, K., Houston, J. E., \& Griffiths, M. D. (2012). Excessive eating and compulsive buying behaviors in women: An empirical pilot study examining reward sensitivity, anxiety, impulsivity, self-esteem and social desirability. International Journal of Mental Health and Addiction, 10(4), 474-489.

D'Astous, A., Maltais, J. and Roberge, C. (1990). Compulsive buying tendencies of adolescent consumers, Advances in Consumer Research, 17, 306-312.

de Mattos, C. N., Kim, H. S., Requião, M. G., Marasaldi, R. F., Filomensky, T. Z., Hodgins, D. C., \& Tavares, H. (2016). Gender differences in compulsive buying disorder: assessment of demographic and psychiatric co-morbidities. PloS one, 11(12), e0167365.

Dean, L. R., Carroll, J. S. and Yang, C. (2007). Materialism, perceived financial problems, and marital satisfaction, Family and Consumer Sciences Research Journal, 35(3), 260-281.

Delacroix, E. (2003). Le Regret Chez Le Consommateur: Un Etat De L'art, Cahier De Recherche.

DeSarbo, E. S. and Edwards, E. A. (1996). Typologies of compulsive buying behavior, Journal of Consumer Psychology, 5(3), 231-262.

Dittmar, H. (2005). Compulsive buying-a growing concern? An examination of gender, age, and endorsement of materialistic values as predictors, British Journal of Psychology, 96(4), 467-491.

Donnelly, G., Ksendzova, M. and Howell, R. T. (2013). Sadness, identity, and plastic in over-shopping: The interplay of materialism, poor credit management, and emotional buying motives in predicting compulsive buying, Journal of Economic Psychology, 39, 113-125.

Ergin, E. A. (2010). Compulsive buying behavior tendencies: The case of Turkish consumers. African journal of business management, 4(3), 333.

Eryılmaz, A. ve Hasan, A. T. A. K. (2014). Ergen öznel iyi oluşunun, öz saygi ve iyimserlik eğilimi ile ilişkisinin incelenmesi, Elektronik Sosyal Bilimler Dergisi, 10(37), 170-181.

Faber, R. J., and Vohs, K. D. (2004). To buy or not to buy?: Self-control and self-regulatory failure in purchase behavior. In R. F. Baumeister \& K. D. Vohs (Eds.), Handbook of self-regulation: Research, theory, and applications (pp. 509-524). New York, The Guilford Press.

Faber, R.J. and O'Guinn, T.C. (1988). Compulsive consumption and credit abuse, Journal of Consumer Policy, 11: 97-109.

Faber, R.J. and O'Guinn, T.C. (1992), A clinical screener for compulsive buying, Journal of Consumer Research, 19(3), 459-469.

Garðarsdóttir, R. B. and Dittmar, H. (2012). The relationship of materialism to debt and financial well-being: The case of Iceland's perceived prosperity. Journal of Economic Psychology, 33(3), 471-481.

Goldberg, M. E., Gorn, G. J., Peracchio, L. A. and Bamossy, G. (2003). Understanding materialism among youth, Journal of Consumer Psychology, 13 (3), 278-288.

Hair, J.F., Black, W.C., Babin, B.J. and Anderson, R.E. (2010). Multivariate Data Analysis, Seventh Edition, NewYork, Prentice Hall.

Hanley, A. and Wilhelm, M. S. (1992). Compulsive buying: An exploration into self-esteem and money attitudes. Journal of economic Psychology, 13(1), 5-18.

Inseng, D. H., \& Teichert, T. (2016, July). The impact of generation y money attitudes on compulsive buying: contingency effects of childhood family resources and gender. In 2016 Global Marketing Conference at Hong Kong (pp. 69-79).

Islam, T., Wei, J., Sheikh, Z., Hameed, Z., and Azam, R. I. (2017). Determinants of compulsive buying behavior among young adults: The mediating role of materialism, Journal of adolescence, 61, 117-130. 


\section{O. Karahan - C. Söylemez 11/3 (2019) 1961-1975}

Kalaycı, Ş. (2010). SPSS Uygulamalı Çok Değişkenli İstatistik Teknikleri, Ankara, Asil Yayın.

Kaynak, E. ve Harcar, T. (2001). Consumers' attitudes and intentions towards credit card usage in an advanced developing country. Journal of Financial Services Marketing, 6(1), 24-39.

Kline, Rex B. (2011). Principles and practice of structural equation modeling, Third Edition, London, The Guilford Press.

Kukar-Kinney, M., Scheinbaum, A. C., \& Schaefers, T. (2016). Compulsive buying in online daily deal settings: An investigation of motivations and contextual elements. Journal of business research, 69(2), 691-699.

Landman, J. (1993). Regret: The persistence of the possible. England, Oxford University Press.

Lee, S. H. and Cotte, J. (2009). Post-Purchase Consumer Regret: Conceptualization and Development of the PPCR Scale, Advances in Consumer Research, 36, 456- 462.

Lee, S.-H., \& Workman, J. (2015). Compulsive buying and branding phenomena. Journal of Open Innovation: Technology, Market, and Complexity.

Lee, S., Park, J., \& Bryan Lee, S. (2016). The interplay of Internet addiction and compulsive shopping behaviors. Social Behavior and Personality: an international journal, 44(11), 1901-1912.

Luo, X. (2005), How does shopping with others influence impulsive purchasing, Journal of Consumer Psychology, $15(4), 288-94$.

Mangleburg, T. F., and Bristol, T. (1998). Socialization and adolescents' skepticism toward advertising, Journal of Advertising, 27(3), 11-21.

McElroy, S. L., Keck, P. E., Pope, H. G., Smith, J. M., and Strakowski, S. M. (1994). Compulsive buying: a report of 20 cases, The Journal of clinical psychiatry, 55(6), 242-248.

Moon, M. A., Rasool, H., \& Attiq, S. (2015). An analysis of compulsive buying behavior: Questioning the role of marketing campaigns. Journal of Marketing and Consumer Research, 16, 97-101.

Moulding, R., Duong, A., Nedeljkovic, M., \& Kyrios, M. (2017). Do you think that money can buy happiness? A review of the role of mood, materialism, self, and cognitions in compulsive buying. Current Addiction Reports, 4(3), 254-261.

Mowen, J. C. and Spears, N. (1999). Understanding compulsive buying among college students: A hierarchical approach, Journal of Consumer Psychology, 8(4), 407-430.

Nakip, M. (2013). Pazarlama Araştırmaları Teknikleri (SPSS Uygulamalı), 3. Baskı, Ankara, Seçkin Yayınevi.

Noh, M., Hasan, H. M. R. ul (2017). Moderating effect of personality traits on relationships between retail therapy, compulsive buying, and hoarding for fashion products. Journal of Global Fashion Marketing, 8(3), 180-192.

O'Guinn, T. C. and Faber, R. J. (1989). Compulsive buying: A phenomenological exploration, Journal of Consumer Research, 16 (2), 147-157.

Oliver Richard, L. (1997). Satisfaction: A behavioral perspective on the consumer, New York, Irwin-McGraw-Hill.

Omar, N. A., Rahim, R. A., Wel, C. A. C., \& Alam, S. S. (2014). Compulsive buying and credit card misuse among credit card holders: The roles of self-esteem, materialism, impulsive buying and budget constraint. Intangible Capital, 10(1), 52-74.

Palan, K. M., Morrow, P. C., Trapp, A., and Blackburn, V. (2011). Compulsive buying behavior in college students: the mediating role of credit card misuse, Journal of Marketing Theory and Practice, 19(1), 81-96.

Pandey, S. K. (2016). The effect of deals and moods on compulsive buying: A study on young Indian consumers. Global Business Review, 17(2), 438-449.

Punch, Keith F. (2005). Sosyal Araştırmalara Giriş: Nicel ve Nitel Yaklaşımlar, Dursun, Bayrak, H. Bader, ARSLAN ve Zeynep, AKYÜZ, (Çev.), 1. Baskı, Ankara, Siyasal Yayınevi. 


\section{O. Karahan - C. Söylemez 11/3 (2019) 1961-1975}

Raab, G., Elger, C. E., Neuner, M. and Weber, B. (2011). A neurological study of compulsive buying behaviour, Journal of Consumer Policy, 34(4), 401.

Richins, M. L. and Dawson, S. (1992). A consumer values orientation for materialism and its measurement: Scale development and validation, Journal of consumer research, 19(3), 303-316.

Richins, M. L. and Rudmin, F. W. (1994). Materialism and economic psychology, Journal of Economic Psychology, 15(2), 217-231.

Ridgway, N. M., Kukar-Kinney, M. and Monroe, K. B. (2008). An expanded conceptualization and a new measure of compulsive buying, Journal of consumer Research, 35(4), 622-639.

Roberts, J. A., Pullig, C., \& David, M. (2019). Family conflict and adolescent compulsive buying behavior. Young Consumers.

Rosenberg, M. (1965). Society and the Adolescent Self-Image, Princeton, Princeton University Press.

Scherhorn, G., Reisch, L.A., and Raab, G. (1990). Addictive buying in west germany: An emprical study, Journal of Consumer Policy, 13, 355-387.

Schneider, F. and Kirchgässner, G. (2009). Financial and world economic crisis: What did economists contribute?, Public Choice, 140(3-4), 319-327.

Strizhakova, Y., Coulter, R. A. and Price, L. L. (2008). The meanings of branded products: A cross-national scale development and meaning assessment, International Journal of Research in Marketing, 25(2), 82-93.

Tsiros, M. and Mittal, V. (2000). Regret: A model of its antecedents and consequences in consumer decision making, Journal of Consumer Research, 26, 401-417.

Villardefrancos, E., \& Otero-López, J. M. (2016). Compulsive buying in university students: its prevalence and relationships with materialism, psychological distress symptoms, and subjective wellbeing. Comprehensive psychiatry, 65, 128-135.

Wang, J., and Xiao, J. J. (2009). Buying behavior, social support and credit card indebtedness of college students, International Journal of Consumer Studies, 33(1), 2-10.

Yurchisin, J. and Johnson, K.K. (2004). Compulsive buying behavior and its relationship to perceived social status associated with buying, materialism, self-esteem, and apparel-product involvement, Family and Consumer Sciences Research Journal, 32(3), 291-314.

Zerach, G. (2016). The mediating role of emptiness and materialism in the association between pathological narcissism and compulsive buying. International Journal of Mental Health and Addiction, 14(4), 424-437.

Zeelenberg, M. and Pieters, R. (2007). A theory of regret regulation 1.0, Journal of Consumer Psychology, 17, 318. 